\title{
LANGUAGE-INTERNAL VERSUS CONTACT-INDUCED CHANGE: THE SPLIT CODING OF PERSON AND NUMBER: A STEFAN ELDERS QUESTION ${ }^{1}$
}

\author{
Zygmunt Frajzyngier \& Erin Shay \\ University of Colorado, Boulder, Colorado, USA
}

\section{Introduction}

When a typologically rare phenomenon is exhibited in neighboring languages that have no common ancestor, the question arises whether the phenomenon may be the product of languageinternal development or a product of language contact. The aim of the present paper is to contribute to the methodology for answering such questions. The test problem for our theoretical discussion is a construction consisting of Subject pronoun-Verb-Plural marker, where the subject pronoun codes person only and the suffix codes the plurality of the subject. We propose language-internal prerequisites for the grammaticalization of such structures for two related languages, Gidar and Giziga (Afroasiatic; Central Chadic). We provide evidence that the phenomenon exists in the unrelated but neighboring language Mundang (Niger-Congo; Adamawa). We consider two explanations for this phenomenon: language contact and language-internal grammaticalization.

\footnotetext{
${ }^{1}$ Work on this paper was supported by NSF grant No. 0439940, which allowed Z.F. to gather the most recent data on Wandala and Giziga. The data on Gidar and Hdi were gathered with the support of grants from the NEH (Complex Sentence in Chadic) and from the NSF (Grammars of Four Chadic languages). This work was also supported by the University of Colorado Faculty Fellowship granted to Zygmunt Frajzyngier. The data on Wandala were gathered in Cameroon, where Frajzyngier was hosted over many years by the Institut de Recherche Agricole pour le Développement in Maroua, which also provided him with much-needed institutional and logistic support. We are most grateful to its current director, Dr. Noé Woin, for support during the years 2004-2006. The data for Mupun were gathered many years ago with the support of NSF, $\mathrm{NEH}$, and the University of Colorado.

We would like to thank the following colleagues for sharing their knowledge with us for purposes of this paper: Suzanne Ruelland, for Tupuri; David Rood, for Lakhota; and Ulrich Kleinewillinghöfer, for Waja. We are also grateful to all of the institutions that have supported the work on various Chadic languages. We would also like to thank the anonymous reader of this paper for the insightful reading and constructive comments. None of these people or institutions is responsible for the hypotheses, methods, and conclusions reached in this paper, and we alone are responsible for all errors of facts or interpretation.
} 


\subsection{The problem}

Several languages spoken in Northern Cameroon have structures wherein a subject pronoun coding person is followed by the verb, with a suffix coding plurality of the subject. The object, if any, follows the verbal piece. This is illustrated in Mundang (plural suffixes bolded):
?à
ngòn-rā
gíi
S.3S:IM
cut:VN-PL
goat

'They slaughter a goat.'

Compare the singular:

$\begin{array}{lll}\text { Pà } & \text { ngòn } & \text { gíì } \\ \text { S.3S:IM } & \text { cut:VN } & \text { goat }\end{array}$

'He slaughters a goat.' (Elders 2000: 160)

An identical construction with different phonological realization is found in the unrelated but neighboring Gidar:

à-ssóhọ̀-wó-n-kà

3M-ask-1SG-PL-PRF

'They asked me.'

Compare the singular:

$$
\begin{aligned}
& \text { à-ssóhọ̀-w-kà } \\
& \text { 3M-ask-1SG-PRF }
\end{aligned}
$$

'He asked me.' (Frajzyngier 2008)

Structures in which the morpheme coding person is separated by other material from the morpheme coding number appear to be rare across languages (Dryer, p.c.), and such structures are not discussed in Daniel 2005, Bhat 2005, or other articles dedicated to pronouns in Haspelmath et al. 2005. Among the languages so far identified as exhibiting this structure are Gidar, Daba, Giziga and Mofu-Gudur, all members of the Central branch of the Chadic family; Mundang (Elders 2000) and Tupuri (Ruelland 1992 and p.c.), both members of the Adamawa branch of the Niger-Congo family; and perhaps Waja (Kleinewillinghöfer, p.c.), a member of either the Adamawa or Gur branch of the same family. A similar construction is also found in some Cushitic languages (Zaborski 1975), Egyptian (Loprieno and Müller (to appear)) and in Lakhota (Siouan). The construction is widespread among the native languages of North America (David Rood, p.c.).

Languages discussed in this study are spoken in a relatively small area of northern Cameroon. Gidar, Mundang and Tupuri form a geographic grouping, with Gidar speakers bordering Mundang to the west and Tupuri speakers bordering Mundang to the east. Speakers of Giziga, Mofu-Gudur and Daba form a second grouping; these three languages are in very close proximity to one another and about 40 kilometers from Gidar, Mundang and Tupuri. The geographical proximity of the Central Chadic and Adamawa languages suggests that language contact could be a factor in the 
shared occurrence of this rare phenomenon. If language contact is responsible for the shared structure in northern Cameroon, the question is where the phenomenon originated and where it is a product of language contact. The constructions in question are very rare in Chadic languages, having been attested only in Gidar, Daba, Giziga, and Mofu-Gudur, and appear to be rare in the Adamawa languages (Elders p.c.). ${ }^{1}$ An explanation relying on language contact would still need to explain how the construction in question emerged in the donor/source/model language. For this reason, we propose a search for language-internal motivation as the methodological starting point.

\subsection{Organization of the study}

We first analyze the relevant constructions in Gidar and Giziga, both members of Central Chadic, using internal reconstruction and comparative evidence. We also examine two Central Chadic languages that do not have this construction but whose structure supports our hypothesis about the necessary conditions for the presence of the relevant constructions. We then describe the relevant constructions in the Adamawa language Mundang and in the Siouan language Lakhota.

\section{Hypothesis}

We propose that the split coding, i.e. the coding of person before the verb and number after the verb, emerges as a result of language-internal prerequisites: (1) The existence of separate morphemes for the coding of person and number; and (2) the overt coding, in preverbal position, of subjects of all persons in at least some aspects or tenses. The hypothesis is not tautological, because in many languages the morphemes coding person and number are separate but adjacent.

The evidence for the hypothesis consists in demonstrating that the construction Subject pronounVerb is an innovation in Chadic languages; that forms coding third-person subjects in such constructions emerged more recently than first- and second-person subject pronouns; and that the coding of person and number by different morphemes is a retention from an older grammatical system.

\section{Gidar}

We shall demonstrate that the split coding of person and number in Gidar is a product of language-internal development, motivated by (1) the existence of different morphemes for person and number in the second and third person, and (2) the occurrence of subject pronouns before the verb.

\subsection{Split coding of person and number in Gidar}

The purpose of this section is to demonstrate the split coding of person and number in Gidar. The following table illustrates pronominal subject markers in Gidar. Person markers are prefixes in some dialects of Gidar and free morphemes in others, although no other morphemes may occur between the person marker and the verb:

\footnotetext{
${ }^{1}$ This study is dedicated to Stefan Elders, who drew our attention to the split coding of person and number in Mundang and who agreed to work with us on this study shortly before his tragic death. We had hoped to include a comparative study of languages in the Adamawa branch in the present study; however, for the time being this task must be left undone.

Stefan Elders did not see the abstract or the outline of this study, and therefore we cannot say whether he would have shared our hypotheses, conclusions, or methodology. The information that no other Adamawa language apart from Tupuri has a construction resembling that found in Mundang comes from Stefan Elders.
} 
Table 1. Pronominal subjects in Gidar

\begin{tabular}{lll}
\hline Person & Singular & Plural \\
\hline First & nò & mò \\
Second & kə̀ & kə̀ . àn(î̀)* \\
Third masculine & à & à . àn(ì) \\
Third masculine & dò & dò ... àn(ì) \\
focus & & \\
Third feminine & tò & \\
\hline
\end{tabular}

*ànì becomes àn in phrase-internal position

In the perfective and imperfective aspects, the person of the subject is coded by a pronoun before the verb. Second- and third-person plural pronominal subjects are coded by discontinuous morphemes. A subject pronoun preceding the verb codes person and a marker suffixed to the verb codes number:

$$
\begin{array}{ll}
\text { ò-tóy.g-ón-k } & \text { éngílì } \\
\text { 3M-enter-PL-PRF } & \text { PREP:home }
\end{array}
$$$$
\text { é né-t }
$$$$
\text { dà }
$$$$
\text { 'They entered their houses.' }
$$

\section{PREP GEN-3PL LOC}

Cf. the singular:
(6)
ò-tón-k
éngíl
3M-enter-PRF PREP:home
'He entered his house.'
á
ná-n
dà
PREP
GEN-3M
LOC

The suffix coding number is identical for both second and third person. As in all Chadic languages, there is no gender distinction in the plural. In Gidar, the third-person plural is coded by the third-person masculine pronoun and the plural suffix.

The suffix coding plurality of the second- and third-person plural subject is identical with the third-person object pronoun. In the second- and the third-person plural, the verb must also take the totality marker $w$, which becomes $u$ after some consonants and subsequently is lowered to $o$ before a word-final nasal. One of the functions of the totality extension is to code the plurality of the event:

$$
\begin{array}{llll}
\text { á } & \text { jáa6è } & \text { kò-dá } & \text { ss-ó- } y \\
\text { PREP } & \text { Djabe } & \text { 2P-FUT } & \text { be-TOT-PL }
\end{array}
$$

'It is in Djabe that you (PL) will be.'

$$
\begin{array}{llll}
\text { á } & \text { jáabè } & \text { à-dá } & \text { ss-ó- } y \\
\text { PREP } & \text { Djabe } & 3 M-F U T & \text { be-TOT-PL }
\end{array}
$$

'It is in Djabe that they will be.'

In the future tense of pragmatically independent clauses (see Frajzyngier 2004), the third-person 
plural does not have a subject pronoun preceding the verb (although it is possible that the subject pronoun $a$ fused with the future marker wá):

$$
\begin{aligned}
& \text { wá só-n á jáabè } \\
& \text { FUT be:TOT-PL PREP Djabe }
\end{aligned}
$$

$$
\begin{array}{llll}
\text { wá kò-só- } y & \text { á } & \text { jáabè } \\
\text { FUT 2-be:TO-PL } & \text { PREP } & \text { Djabe } \\
\text { 'You (PL) will be in Djabe.' }
\end{array}
$$

Evidence that the marker of subject plurality is independent of the marker of the person is provided by clauses with an indirect object. In such clauses, when the verb is not a verb of giving, the plurality of the subject is coded twice: once by the suffix $-n$ added to the verb and once by the same suffix in the dative/benefactive phrase after the suffix pronouns coding the beneficiary:

$$
\begin{array}{lll}
\text { à-lbàhá-n } & \text { sò-wó-nò-k } & \text { wàłíyà } \\
\text { 3M-buy-PL } & \text { DAT-1SG-PL-PRF } & \text { cow } \\
\text { 'they bought a cow for me' } &
\end{array}
$$

Compare the singular subject:

$$
\begin{aligned}
& \text { à-lbà sò-wó-k wàtíyà } \\
& \text { 3M-buy DAT-1SG-PRF cow }
\end{aligned}
$$

'He bought a cow for me.'

\subsubsection{Emergence of preverbal subject markers}

In order to understand how the split coding of plurality of the second- and third-person subject in Gidar came about, it is necessary to reconstruct the grammaticalization of pronominal subject markers. Some elements of this information can be gleaned from the examination of other Chadic languages and some from the internal reconstruction of Gidar.

In Frajzyngier (1983), it is argued that Proto-Chadic had Verb-Subject order for nominal and pronominal arguments. The main argument for this hypothesis was that there are many constructions in Chadic in which the subject is placed before the verb in an otherwise verb-initial language in order to code a specific function, such as contrastive or other focus; backgrounding; topicalization; switch-reference; and the coding of certain aspects and tenses. However, there is no attested rule in contemporary Chadic languages that moves the subject from the position before the verb to the position after the verb in a language that is otherwise subject-initial. Likewise, there is no rule that places the subject in the position at the end of clause.

In a language with preverbal subject pronouns, such as Gidar, the question is where the subject pronouns in preverbal position come from. We propose that preverbal subject pronouns emerged as Chadic languages shifted from the Verb-Subject structure to the Subject-Verb structure. There are two possible sources for preverbal pronouns: (1) An existing postverbal subject pronoun was moved into preverbal position; or (2) preverbal subject pronouns were grammaticalized from other sources 
and placed in preverbal position. We propose that first- and second-person singular pronouns inserted into the preverbal position were drawn from the set of independent pronouns, while thirdperson singular pronouns were grammaticalized from other sources, most likely deictic demonstratives. We further propose that third-person singular pronouns, whether before or after the verb, are comparatively recent innovations, a factor which may have contributed to the development of split coding of person and number. The evidence is presented here.

The first-person singular pronoun has the consonant $n$ in a great many Chadic languages of all branches (Dittemer et al. 2004: 76, 78), as it does in Gidar. A number of other Chadic languages have the palatal glide $y$ as a component of the first-person singular pronoun. Some languages, e.g. Wandala (Central branch), have first-person singular pronouns of both types, used in different constructions. We may thus posit the form nò in Gidar as a retention from an earlier stage. The second-person singular marker can be easily reconstructed for Proto-Chadic as having the initial consonant $k$, by far the most frequent component of the second-person singular pronoun in contemporary Chadic.

The third-person singular (masculine) pronoun cannot be reconstructed with equal confidence. Third-person masculine singular pronouns (or simply third-person singular pronouns, in languages without a gender distinction in the pronoun system) display a wide variety of forms, including forms beginning with $s, y, n, r, m, t, a, d, j, l, g, t s$, glottalized $d$, and the velar nasal $\eta$ (for a list of pronouns in Chadic, see Dittemer et al. 2004: 72-75). There are also languages that do not have a third-person singular (masculine) subject pronoun. The lack of uniformity among third-person singular pronoun forms suggests that Proto-Chadic did not have a third-person singular (masculine) subject pronoun as a separate category. Third-person pronouns with the consonants $s, y, n, d$, and the vowel $a$ are most likely derived from deictic demonstratives. In Hdi (Central Chadic), for example, the series of demonstratives and determiners includes forms beginning with $a, y, n$, and $t s$ (Frajzyngier with Shay 2002). Other languages have demonstratives beginning with $d$. The development of third-person pronouns from demonstratives across languages is well established in the linguistic literature (Kurylowicz 1964; Greenberg 1978; for Chadic, Schuh 1983).

The hypothesis that the third-person pronoun in Proto-Chadic was unmarked provides an explanation for a characteristic of some contemporary Chadic languages: In some languages that have both Subject-Verb structures and Verb-Subject structures, e.g., in different aspects and tenses, the third-person pronoun is often unmarked in the Verb-Subject structure. Wandala, for example, has no third-person singular subject marker in the perfect aspect. Additional evidence for the shift from Verb-Subject to Subject-Verb order and the relatively recent innovation of third-person singular subject pronouns is provided by languages with both pre- and postverbal subject pronoun paradigms or with different pronoun paradigms for different tenses, aspects or moods. In Hdi (Central), the third-person subject pronoun is unmarked in the perfective aspect. In the imperfective aspect, the third-person subject pronoun is marked after the verb (Frajzyngier with Shay 2002). In paradigms where the subject pronoun occurs before the verb, a deictic form is drafted to serve as third-person pronoun. In Mupun (West Chadic), a consistent SVO language, where first- and second-person pronouns are reflexes of the Proto-Chadic pronouns, the third-person pronoun has been grammaticalized from a lexeme meaning 'fellow'.

The third-person masculine pronoun $a$ in Gidar may once have been a deictic or an anaphoric marker. Evidence for this is provided by the grammaticalization of the form $a$ in post-verbal position as a goal marker (called 'point of view of object' in Frajzyngier 2008). The goal marker indicates that the event has a goal. With transitive verbs, the marker contrasts the presence of a goal with the event without a goal. With intransitive verbs, the marker may have a transitivizing function: 
(13)

$$
\begin{aligned}
& \text { á-s-á } \\
& \text { IMPER-drink-GO } \\
& \text { á-zóm-á }
\end{aligned}
$$$$
\text { IMPER-eat-GO }
$$

$$
\begin{aligned}
& \text { 'drink it!' } \\
& \text { 'eat it!' }
\end{aligned}
$$

\section{.}

The third-person masculine subject pronoun in Gidar is also $\grave{a}$, which might suggest that the third-person subject marker was moved from postverbal to preverbal position. Given the function of the goal marker, this movement would be completely unmotivated. It is very possible, however, that the subject marker $a$ and the goal marker $a$ derive from the same deictic or anaphoric marker, which would support the hypothesis that Verb-subject is the older order and that third-person subject pronouns are a relatively recent innovation.

\subsection{Object marker in Gidar}

The purpose of this section is to explain the origins of the second- and third-person subject plural marker in Gidar. More specifically, we demonstrate that the plural marker has emerged from the erstwhile object marker. We have postulated that a prerequisite for the split coding of person and number is the existence of a morpheme whose sole function is to code number. Since some languages have dedicated markers whose function is to code plurality of the subject and some do not, it is necessary to explain how such markers emerged.

In many Chadic languages, the marker of subject plurality has fused with the marker of person. In Central Chadic languages, the first-person plural exclusive and the second- and third-person plural pronouns appear to be complex structures, both synchronically or diachronically, consisting minimally of person marking and plural number marking (cf. tables in de Colombel 1998). Secondperson plural pronouns have the initial consonant $k$, corresponding to the second-person singular pronoun, followed by a nasal consonant. The first-person plural pronoun inclusive has the initial consonant $m$ in many Central Chadic languages. The consonant $m$ is also found in the first-person plural forms in many languages from other branches of Chadic where there is no distinction between inclusive and exclusive pronouns. The first-person plural can be safely reconstructed for Proto-Chadic with this form and function (de Colombel 1998, repeated in Tourneux 2004). Thirdperson plural pronouns, like third-person singular pronouns, show much more variation in consonantal structure than do first- and second-person plural pronouns, providing additional evidence that third-person pronouns are relative innovations.

We postulate that the structure of the verbal piece in Proto-Chadic was Verb-Pronoun-Plural, where the pronoun coded person only and the third-person pronoun was unmarked. The only indication of the third-person plural was the marker of plurality. In some languages, the person marker fused with the plural marker, but in some languages this fusion did not occur. In these languages, when the subject pronoun was placed before the verb to code some particular function, the number marker remained in situ. Since the third-person subject was unmarked, the third-person preverbal pronoun was introduced into preverbal position from another source.

Frajzyngier (1997) proposes that the marker of subject plurality derives historically from the third-person object marker. In Gidar, the marker of subject plurality àn(i) is phonologically identical with the third-person masculine object pronoun, which is deployed only to code definiteness of the object. If the verb has an object suffix, the plural subject suffix follows the object suffix. Further evidence for the source of the plural morpheme is that the plural subject marker occupies the position after the verb, i.e. the position of an object pronoun: 
Table 2. Pronominal objects in Gidar

\begin{tabular}{lll}
\hline Person & Singular & Plural \\
\hline First & -wà & -m \\
Second & -kù & -kúm \\
Goal marker & -á & \\
Third masculine & -nì or $(-n),-$ á & -i, -ti \\
Third feminine & -tà & \\
\hline
\end{tabular}

The third-person masculine object is realized as ni in a number of structures, including the progressive aspect, where the object noun occurs in preverbal position:
mà wín tà-t ózgál-nì
mother child PROG-F feed-3M
'The mother is feeding the baby (M).'

When the subject is second- or third-person plural, i.e., when plurality of the subject is coded by the suffix $n$, the third-person masculine singular object also is coded by the form $n$. An epenthetic vowel is inserted if syllable structure conditions require it:

(15)

$$
\text { à-pə̀rm-nó-n-kà }
$$

'They heard it.'

(16)

kว̀-hál-nó-n-kà

2P-steal-3M-PL-PRF

'You (PL) robbed him.'

(17) kว̀-və̀r-nó-n-kà

2P-hit-3M-PL-PRF

'You (PL) hit him.'

In the Lam dialect, the plural suffix $n i$ occurs in phrase-final position in the dependent perfective, the progressive, and the future tense:

In some dialects, the object marker nì may be reduced to a consonant only, even in clause-final position. If vowel deletion creates a disallowed consonant cluster, an epenthetic high central vowel (represented as schwa) is inserted: 


$\begin{array}{lll}\text { (19) áfú-n } & \text { wín tà-yí } & \text { zgə̀lá-n } \\ \text { father-3M child PROG-3M } & \text { feed-3M } \\ \text { 'The father is feeding the baby (M).' } & \end{array}$

We have shown that plural subject markers are identical with, and occupy the same position as, one of the third-person singular masculine object markers in Gidar. We have shown that the independent coding of person and number in Gidar is a product of language-internal development, motivated by (1) the absence of second- and third-person subject pronouns coding the categories person and number; (2) the need for subject pronouns to occur before the verb; and (3) the existence of a morpheme whose sole function is to code plurality of the subject.

\section{Giziga}

In Giziga (Central Chadic), the person of the subject is coded by a preverbal marker and the plurality of the subject is coded by a verbal suffix. The split coding of person and number of the subject pronoun applies to all persons in all aspects and tenses. We describe the coding system in Giziga and posit language-internal motivations for the development of split coding of the person and number of the subject.

Every pragmatically independent clause (see Frajzyngier 2004) in Giziga requires a preverbal subject pronoun, even if the clause also has a subject. Giziga has two different plural suffixes, am and $k$, either of which may code plurality of the first-, second- or third-person subject.

Table 3. Subject pronouns in Giziga (except where noted, Giziga data are from Frajzyngier field notes/Shay in progress):

\begin{tabular}{lll}
\hline Person & Singular & Plural \\
\hline First & yi & yi . . am \\
& & yi ... k \\
Second & ki & ki . . am \\
& & ki ... k \\
Third masculine & a & a . . am \\
& & a ... k \\
\hline
\end{tabular}

$\begin{array}{llll}\text { kí vl-àm hìn lè } & \\ 2 & \text { give-PL day } & \text { EE }\end{array}$

'You (pl) set a date.'
kí pr-à-k-á
lè
2 see-GO-PL-3SG EE
'You (pl) saw it.'

The Giziga first-person pronoun yi may be considered a retention from Proto-Chadic, based on the high incidence of the palatal glide in synchronic first-person singular forms (Dittemer et al. 
2004). The second-person subject pronoun ki may also be considered a retention from the ProtoChadic second-person pronoun, for which we have posited an initial $k$ (above). Since it is not possible to reconstruct a single consonant or vowel as the Proto-Chadic third-person subject pronoun, we consider the third-person pronoun $a$ in Giziga to belong to the group of third-person pronouns derived from deictic markers. The third-person subject pronoun in Giziga thus represents a more recent grammaticalization than either the first- or second-person pronoun.

The distribution of the plural suffixes $a m$ and $k$ is as follows: If plurality of the subject is the only category marked by a verbal suffix or extension, plurality is marked by $a m$. Tone on the subject marker and suffixes codes tense and aspect:

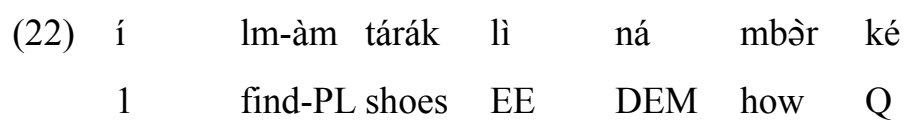

'We have found shoes, so what now?'

$\begin{array}{lccccc}\text { (23) á } & \text { wd-ám } & \text { bà } & \text { zò6-ám } & \text { vú } & \text { bè'é } \\ 3 & \text { want-PL } & \text { HYP } & \text { take-PL } & \text { body } & \text { PAST } \\ & & & \end{array}$

If more than one category is marked by a verbal suffix or verbal extension, plurality of the subject is marked by the suffix $k$. Categories that may be marked by verbal inflection include ventive; goal; movement away; and direct or indirect object. When the verb has the goal marker $a$, plurality of the subject is marked by $k$. The presence of the goal marker with a nominal direct object codes referentiality of the object. In the Giziga dialect spoken in Muturua, a copy of the vowel following the plural marker is inserted between the plural marker and the stem:

$\begin{array}{llll}\text { (24) á } & \text { lm-á-k-à } & \text { zùy-tán } & \text { tá } \\ 3 & \text { find-V-PL-GO } & \text { child-3PL } & \text { NEG }\end{array}$

'They didn't find their child.'

Without the goal marker, the object is non-referential, and plurality of the subject is marked by am:

$\begin{array}{lllll}\text { (25) á } & \text { lm-ám } & \text { zùn } & \text { tá } \\ 3 & \text { find-PL } & \text { child } & \text { NEG } \\ \\ \text { 'They didn't find a child.' }\end{array}$

A direct object pronoun after the verb also triggers use of the plural suffix $k$. In the Muturua dialect, a copy of the direct object pronoun is inserted between the stem and the plural suffix:

With an intransitive verb, the presence of the ventive suffix áwà triggers coding of subject 
plurality by the suffix $k$. A copy of the ventive suffix, which becomes ò in phrase-internal position, is inserted between the stem and the plural suffix:

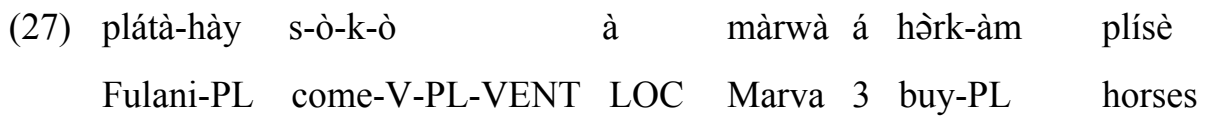

'The Fulani came to Marva, and they bought horses.'

It appears to be the presence of the goal marker that triggers use of the marker $k$ to code subject plurality. In the Giziga dialect spoken near Lam, the center of the Gidar language area, the vowel between the verbal stem and the plural suffix is /a/, identical with the goal marker:
(28) fèdèmèy
á rá sp-á-k-ì
pig-PL

3
PROG seek-V-PL-1SG

'The pigs are looking for me.'

$\begin{array}{llll}\text { fèdèmèy } & \text { á } & \text { rá } & \text { sp-á-k-ù } \\ \text { pig-PL } & 3 & \text { PROG } & \text { seek-V-PL-2SG }\end{array}$

'The pigs are looking for you.'

Compare the Muturua dialect, where the goal marker assimilates completely to the vowel following the plural marker:

\begin{tabular}{lll} 
(30) fèdèm-èy & rá & \multicolumn{1}{l}{$\mathbf{s p - i ́ - k - i ̀ ~}$} \\
pig-PL. 3 & PROG & seek-V-PL-1SG
\end{tabular}

'The pigs are looking for me.'

$\begin{array}{llll}\text { (31) fèdèmèy } & \text { á } & \text { rá } & \text { sp-ú-k-ù } \\ \text { pig-PL } & 3 & \text { PROG } & \text { seek-V-PL-2SG }\end{array}$

'The pigs are looking for you.'

The ventive marker áwà, which codes motion towards the place of speech or other deictic center, may well be composed of the goal marker and a deictic demonstrative. The presence of the goal marker explains the use of the plural marker $k$ with the intransitive verb:
(32) á
m-ó-k-ò
lè ggáy-dù
3 return-V-PL-VENT
EE PREP.house-1SG
'They returned to me.'

Lukas 1970 analyzes the distribution of the two plural suffixes in Giziga as follows: Plurality of the subject is marked by am in pre-pausal position or when the verb is immediately followed by another lexical or grammatical morpheme, while plurality of the subject is marked by $k$ (analyzed by Lukas as $a k$ ) only when the plural form is followed by a direct object pronoun (Lukas 1970: 60-61). When $k$ codes plurality of the subject of an intransitive verb, as is the case when the 
verb is followed by an extension, Lukas states that the use of $k$ 'die Enge des [Verbal]komplexes anzeigt' (Lukas 1970: 68). He does not define the nature of this narrowness (Enge). All of Lukas's statements about the choice of plural marker are explicitly tentative.

Evidence that the choice of $k$, rather than $a m$, as marker of subject plurality is triggered by the presence of the goal marker and not by the nature of the verb itself is that there are many examples of transitive verbs with subject plurality marked by $a m$. The evidence for transitivity is the presence of an unmarked noun in the position after the verb:

$\begin{array}{llllll}\text { (33) í } & \text { diy-àm } & \text { bí } & \text { à } & \text { wàlá-ndrà } & \text { táná } \\ 1 & \text { arrange-PL } & \text { word } & \text { LOC } & \text { among-1PL } & \text { only }\end{array}$

'We settled things between ourselves.'
(34) à kàd-ám ygàngày
3 hit-PL drums

'They beat drums.'

The correlation between the plural marker $k$ and the goal marker suggests possible origins for the two plural markers. Frajzyngier 1997 postulates that markers of subject plurality derive historically from third-person object markers. A possible source for the plural marker $k$ is the proximate deictic $k a ́$ :

$$
\begin{array}{llll}
\text { (35) î́á } & \text { nà } & \text { kà } \\
& \text { meat } & \text { DEM } & \text { PROX }
\end{array}
$$

'The meat is here.'

A possible source for the plural marker $a m$ is the non-referential object marker mi, which occurs in content questions about the inanimate direct object. This marker appears to be a retention from Proto-Chadic (Frajzyngier 2002 (1985): 203):

$\begin{array}{lllll}\text { (36) à } & \text { gì } & \text { mí } & \text { kè } \\ & 3 & \text { make } & \text { what } & \text { Q }\end{array}$

'What does he do?'

When the subject pronoun was placed before the verb to code some particular function, the markers of deictic and non-referential object may have been reinterpreted as coding a category of the subject, namely plurality (cf. Frajzyngier 1997). The fact that only the plural marker $k$ can be used in a clause describing a referential event may be an extension of the referential function of the deictic marker $k a$.

Giziga thus has the language-internal prerequisites for split coding of person and number of the subject: The requirement for preverbal subject pronouns in all independent clauses; the presence of a marker (in this case, two markers) whose sole function is to code plurality; and third-person singular pronouns that are a relatively recent innovation. 


\section{Mofu-Gudur}

Mofu-Gudur (Central Chadic) is closely related to Giziga and is spoken in an area adjacent to speakers of both northern and southern Giziga dialects. Like Giziga, Mofu-Gudur has split coding of person and number for all pronominal subjects. Where southern Giziga distinguishes only firstperson singular and plural, Mofu-Gudur distinguishes first-person singular, dual, plural exclusive and plural inclusive. Like Gidar, Mofu-Gudur does not code the person of the third-person plural subject in some constructions:

Table 4. Subject pronouns in Mofu-Gudur (based on Barreteau 1988: 51)

\begin{tabular}{|l|l|l|l|} 
Person & Singular & Dual & Plural \\
\hline First & ya & ya ... akwa & $\begin{array}{l}\text { Excl.: ya ... am } \\
\text { Incl.: ya . . amákwa }\end{array}$ \\
\hline Second & ka & NA & ka . . am \\
\hline Third & a/ø & NA & a/ø. . am \\
\hline
\end{tabular}

$\begin{array}{ll}\text { (37) a } & \text { kəd-m-ará } \\ 3 & \text { hit-PL-3 }\end{array}$

'They hit it.'

Cf. the singular:

$$
\begin{array}{lll}
\text { (38) a } & \text { kəd-á } \\
& 3 & \text { hit-3 }
\end{array}
$$

'He hit it.' (Barreteau 1988: 52; morpheme separation and glosses ours)

The Mofu-Gudur data provide evidence for am as a marker of plurality independent from the marker of person. The complex morphemes coding the first-person dual and inclusive plural most likely involve the second-person singular pronoun $\mathrm{ka}$.

\section{Comparative evidence}

We present comparative evidence from two other Central Chadic languages in order to demonstrate that (1) in some verbal forms where subject pronouns follow the verb, the third-person singular subject is unmarked; and (2) when the plural marker has fused with the person marker into a single morpheme, the construction Subject pronoun-Verb-Plural marker does not occur.

\subsection{Wandala}

Wandala is a Central Chadic language spoken in the Far North Province of Cameroon and in Northeastern Nigeria. Speakers of Wandala are about 30 kilometers from Hdi, Giziga, and MofuGudur, and more than 100 kilometers from Gidar. (For a description of Malgwa, a language very closely related to Wandala, see Löhr 1999.)

Wandala has no third-person singular subject marker in one aspect, tentatively labeled 'perfect', which is coded by the reduplicated form of the verb. Verbal extensions occur between the two reduplicants (all data from Frajzyngier in progress): 


$$
\begin{aligned}
& \text { (39) zółò màłárà } \\
& \text { finish:APPL-finish now } \\
& \text { 'When that finished,' }
\end{aligned}
$$

Plurality of the subject in this aspect is coded by the form $r$ and the third person remains unmarked:

$$
\begin{aligned}
& \text { (40) é Bà-r-łàlá } \\
& \text { ah depart-3PL-depart } \\
& \text { 'having departed,' }
\end{aligned}
$$

$$
\begin{aligned}
& \text { (41) cúkw-á } \quad \text { ygùdì } \\
& \text { šà-r-n-á-šè }
\end{aligned}
$$

The evidence that the form $r$ codes plurality alone rather than both plurality and person is provided by the fact that this form is also used with the second- and first-person exclusive (but not first-person plural inclusive) subjects:

(42) ám hùd-á hàyè diyà-kùr-díyà án kwà yáwè

IN belly-GEN river know-2PL-know ASSC exist water

'In the river, you know, there is water.'

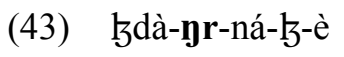
łr-á-nrè
finish-1EXCL-3SG-GO-finish-ABL
work-GEN-1EXCL
'We have finished our work.' (elicited)

In aspects in which subject pronouns precede the verb, the third-person singular is coded by the form $a$ and the third-person plural is coded by the form $t a$ (tones vary depending on tense):
(44)

$\begin{array}{lllllll}\text { à } & \text { błyà } & \text { dùksà } & \text { á-m } & \text { hùd-à } & \text { yáwè } & \text { nà-ní } \\ \text { 3SG } & \text { fall } & \text { thing } & \text { PRED-IN } & \text { belly-GEN } & \text { water } & \text { DEF-INTENS }\end{array}$

'Something falls into this water.'
(45) tà hàrdá zárvà
3PL farm:PL sesame

'They farmed sesame.' 
The data from Wandala show that there are aspects in Central Chadic languages where the thirdperson subject is unmarked, which supports the hypothesis that the third-person subject pronoun is a recent innovation. The plurality of the third person in such aspects in Wandala is coded by the form $r$. The third-person singular subject occurs only in aspects where the subject pronoun precedes the verb. In aspects where the subject pronoun precedes the verb, the third-person plural is coded by the form $t a$, and there is no plural marker $r$ added to the verb. This provides evidence that split marking of person and number does not evolve if there is a single morpheme available that codes both of these categories.

\subsection{Hdi}

Hdi, a Central Chadic Language, is spoken in the Far North Province of Cameroon, in the village of Tourou on the border between Cameroon and Nigeria. Some Hdi speakers live within 20 kilometers of the area where Giziga is spoken. Hdi is a verb-initial language. If a clause has a nominal subject following the verb, the subject pronoun is not marked on the verb:

$\begin{array}{lllll}\text { (46) kà ks-ú-tá } & \text { pákáwá ghúvì tá } & \text { krì } \\ \text { SEQ touch-SO-REF hyena } & \text { OBJ } & \text { dog } \\ \text { 'Hyena devoured Dog.' } & & \end{array}$

In several aspects and moods, the third-person singular subject is not overtly coded, even if there is no nominal subject:

$\begin{array}{llllllll}\text { tsá } & \text { myí-xà } & \text { yá } & \text { ná tà } & \text { dv-áy } & \text { tá } & \text { yà } \\ \text { DEF } & \text { wives-PL } & \text { DEM } & \text { COMP IMPF like-PO } & \text { OBJ } & \text { DEM } \\ \text { tùrtúk } & \text { dvà à } & \text { tá } & \text { yà } & \text { tùrtúk-ù } & & \\ \text { one } & \text { like } \quad \text { NEG } & \text { OBJ } & \text { DEM } & \text { one-NEG } & & \end{array}$

'Among these wives there, (he) likes one and does not like the other.'

(48)

\begin{tabular}{lllll} 
dáwá-f-xà & tá & \multicolumn{2}{l}{ múdúbí } & dáwá-f-xà-tá \\
ask-UP-ALSO & OBJ & \multicolumn{2}{l}{ eyeglasses (Hau.) } & ask-UP-ALSO-REF \\
bábàx ngá & dzà'á & dà & mákwà & \\
shoes FOR & go & PREP & girl &
\end{tabular}

'(He) asked for eyeglasses and (he) also asked for shoes in order to go to a girl.'
(49) díyá-f á wú
germinate-UP NEG NEG
'(It) did not germinate?'

Compare the overt coding of the first-person singular subject: 


$$
\begin{array}{lllll}
\text { (50) } & \text { 6xà-dá-gh-íyù } & \text { tví } & \text { tsá } & \text { wà } \\
\text { arrive-ALL-D:PVG-1SG } & \text { road } & \text { DEF } & \text { NEG }
\end{array}
$$

'I did not get there.'

The third-person plural is coded by the suffix $x \leqslant \tilde{o} n$, which codes both person and number, following the second reduplicant:
dzà’á sá-ghà-sá-xòn
ndá wùdà ndá sígà
FUT arrive-D:PVG-arrive-3PL
ASSC pot
ASSC small pot

'They will come with a wùdà and sígà of beer.'

In the dependent imperfective aspect, when the subject pronouns must be overtly coded, the

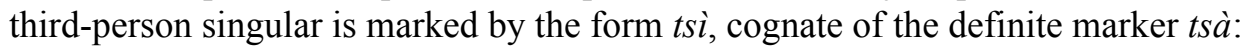
lá-mà krì dá xàd-á kà tà-ná-ghá-tá-tsí
t-’úvá
go-IN dog
PREP here-DEM SEQ find-DEM-D:GO-REF-3SG OBJ-cat
'When Dog entered there, he found Cat.'

The Hdi data illustrate that the third-person singular is unmarked in one aspect (perfective) and that, in aspects where the subject is overtly marked, the third-person subject pronoun is drafted from the set of previous reference markers. The data also show that when a pronoun is available that codes both subject and plurality, there is no independent marker of plurality of the subject.

\section{Split coding of person and number Mundang}

The Niger-Congo languages Mundang and Tupuri, both of which belong to the Adamawa branch and are spoken in Northern Cameroon, have constructions consisting of Pronoun [person] VerbNumber, i.e., the same construction that is found in Gidar, Giziga and Mofu-Gudur. A similar construction also obtains for the unspecified third-person plural in Waja, a member of the Gur branch of the Niger-Congo family that is spoken in Nigeria (Ulrich Kleinewillinghöfer, p.c.).

Mundang, which borders Gidar on the west (see map) and Tupuri on the east, has dedicated subject pronouns for the first-person singular and plural (inclusive and exclusive) and the secondperson singular and plural, as follows:

Table 5. First and second-person subject pronouns in Mundang (Elders 2000: 157)

\begin{tabular}{|l|l|l|}
\hline & \multicolumn{1}{|c|}{ Singular } & \multicolumn{1}{c|}{ Plural } \\
\hline $1^{\text {st }}$ person & mè & $\begin{array}{l}\text { rù (exclusive) } \\
\text { nà (inclusive) }\end{array}$ \\
\hline $2^{\text {nd }}$ person & mò & wì \\
\hline
\end{tabular}


The third-person singular subject is unmarked in the perfective aspect, where the construction consists of the verb, an optional object, and the perfective marker:

$$
\begin{array}{ll}
\text { (53) } \overrightarrow{\text { gi }} & \text { bè } \\
& \text { come }
\end{array}
$$

'He came.'

The plurality of the third-person subject is coded by the suffix rá (realized with mid tone after the verb):
(54)
$\begin{array}{ll}\overrightarrow{\text { gi-rā }} & \text { bè } \\ \text { come-PL } & \text { PERF }\end{array}$
'They came.' (Elders 2000: 160)

Evidence that $r a$ codes number only, and not person and number, is that the third-person subject

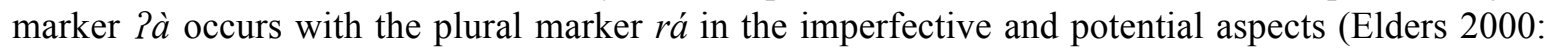
159):

$$
\begin{aligned}
& \text { (55) ?à ngòy-rā gí } \\
& 3 \text { slaughter:VN-PL goat } \\
& \text { 'They slaughter a goat.' (Elders 2000: 160) }
\end{aligned}
$$

Compare the singular:

$$
\begin{array}{lll}
\text { (56) Pà } & \text { ngòy } & \text { gíi } \\
3 & \text { slaughter:VN } & \text { goat } \\
& \text { 'He slaughters a goat.' } &
\end{array}
$$

The marker $r a ́$ is a generalized plural marker that can be used with nouns or verbs. The marker rá by itself and without any person markers can code third-person plural subject in the perfective:

$$
\begin{aligned}
& \text { (57) ngòy-rāa gí bè } \\
& \text { slaughter-PL goat PERF } \\
& \text { 'They slaughtered a goat.' (Elders 2000: 395) }
\end{aligned}
$$

Use of the plural marker rá with the first- and the second-person plural subject is optional. Elders does not comment on its function, and the examples he cites are elicited:

$$
\begin{aligned}
& \text { (58) nà kò-n(-rā) yélì } \\
& \text { S.1PL.INCL see-VN-PL child }
\end{aligned}
$$

'We see a child' (Elders 2000: 396)

The Mundang data show that the motivation for deployment of the third-person singular subject 
pronoun is similar to the motivation in Chadic languages, in that it is required by the form of certain aspectual constructions. Like Chadic languages with split coding of person and number, Mundang has a morpheme whose sole function is to code plurality. The combination of the two factors is sufficient to explain the split coding of person and number in Mundang. Language contact may also have been a factor in the emergence of the split coding, given the contact between Mundang and Gidar.

\section{Lakhota}

Lakhota, a Siouan language spoken in South Dakota (northern U.S.), provides just one example of the split coding of person and number that is widespread among the native languages of North America. The purpose of including the Lakhota data is to further illustrate that the development of a given construction is a function of language-internal properties. When the conditions are met for the split coding of the person and number, the resulting structure may be the same as that found in Gidar, Giziga, Mundang and Tupuri. All information about Lakhota comes from David Rood, p.c., but any mistakes are ours.

Lakhota has a plural marker $p i$ that follows the verb and codes plurality of some pronouns. The language has a split intransitive coding system in which the third-person singular argument is unmarked. The plural marker occurs only with animate arguments. The first table shows the use of the plural marker with subjects of active intransitive or transitive verbs:

Table 6. Subject pronouns in Lakhota:

\begin{tabular}{|l|l|l|l|}
\hline & Singular & Dual & Plural \\
\hline First & wa & uck & uck . pi \\
\hline Second & ya & & ya . . pi \\
\hline Third & $\varnothing$ & & $\begin{array}{c}\emptyset \ldots \text { pi } \\
\text { (intransitives only) }\end{array}$ \\
\hline
\end{tabular}

There is a different set of pronouns for the subjects of stative verbs and the objects of transitive verbs:

\begin{tabular}{|l|l|l|}
\hline & Singular & Plural \\
\hline First & ma & uck . . pi \\
\hline Second & ni & ni . . pi \\
\hline Third & $\varnothing$ & $\varnothing \ldots$ pi \\
\hline
\end{tabular}

There is a separate morpheme, wicha, for animate third-person plural objects or collective subjects of stative verbs.

$\begin{array}{ll}\text { lowã } & \text { 'he/she sang' } \\ \text { lowâpi } & \text { 'they sang' } \\ \text { ûlówâpi } & \text { 'we sang' (David Rood, p.c.) }\end{array}$




\section{Summary}

We have shown that each of the Central Chadic languages in which split coding of the person and number of the subject is attested exhibits the posited language-internal prerequisites: (1) The existence of different morphemes for the coding of person and number; and (2) the overt coding, in preverbal position, of subjects of all persons in at least some aspects or tenses. We have also shown that these languages provide evidence for an earlier stage in which the word order was verb-initial and the third-person singular argument was unmarked. The independent marker of plurality of the subject occurs with all persons in some languages (Giziga and Mofu-Gudur), with second- and third-person subjects in Gidar, and with first-person exclusive, and second-, and third-person subjects in Wandala. Where a single marker codes both person and number of the subject, as is true of some aspects in Wandala, split coding of person and number does not occur.

Mundang, a member of the Niger-Congo language family, has a verbal suffix whose function is to indicate plurality, which could be the plurality of the subject, plurality of the object, and plurality of nouns. Some aspects require a subject pronoun before the verb. In these aspects, a pronoun preceding the subject codes person and the plural suffix on the verb codes number. Mundang thus shares with Chadic languages the language-internal conditions for developing split coding of person and number.

We have shown that the split coding of person and number in Lakhota is also motivated by language-internal factors. Lakhota has a morpheme whose function is to code plurality of the subject. When the subject pronoun is marked overtly, the person and number of the subject are coded separately. Lakhota does not exhibit split coding of person and number in the third person because the third person is the unmarked member of the paradigm. Thus, in all languages of the present study, language-internal requirements have resulted in the development of a similar construction.

A fact we have not addressed is that the third-person pronoun may be coded by the vowel $a$ in both Chadic and Adamawa languages. It would be tempting here to postulate borrowing from one family to another. However, the hypothesis cannot be easily defended, as a number of Chadic languages have a demonstrative/deictic $a$ and there is evidence that pronouns, especially thirdperson pronouns, had deictics and demonstratives as their source.

The third-person pronoun $a$ in Adamawa languages may also have family-internal origin. It occurs in Zarma, a dialect of Songhai, a language belonging to a different branch of Niger-Congo. Given that $a$ occurs throughout the Central Africa as a third-person singular pronoun, and given that $a$ is also a deictic or a determiner in some languages, the marker $a$ as a deictic marker is a potential candidate for an areal feature.

\section{Methodological implications}

When there is a choice between language contact and internal change as an explanation for the sharing of typologically unusual formal structures among unrelated languages, we propose that one should start with an attempt to provide an explanation based on language-internal factors. This proposal is driven by the fact that even when language contact is a factor in language change, one must eventually explain how the structure emerged in the source/donor language. Such an explanation must perforce involve language-internal change. If language-internal motivations in the presumed source language can be found, one must ask whether the presumed target language might have had the same, or similar, internal motivations. An investigation of language change, whether it involves contact or not, must sooner or later posit internal change. When one has established language-internal prerequisites, the absence of those prerequisites may point to language contact as the source of a language form. Language contact may also be a catalyst for the emergence of the phenomenon in a language that has the necessary prerequisites. 
If the presence of split coding of person and number should turn out to be a product of language contact, and if the languages that borrowed this structure already had a means of coding subject plurality, there remains the interesting question of why a language would borrow formal means for a function that it already codes by some other formal means.

\section{Language contact and word order}

A crucial element throughout our discussion is the change from verb-initial word order to subject-initial word order. Assuming that Proto-Chadic was a verb-initial language, we must ask why the majority of Chadic languages have changed to subject-initial order while some have remained verb-initial. Language-internal processes such as topicalization, focus, switch reference, and the use of auxiliaries to form tenses (all postulated in Frajzyngier 1983) are important factors, but they alone may not be sufficient to motivate word order change, since such functions are also found in verb-initial languages. It is very possible that another factor contributing to word-order change is language contact.

An argument in favor of language contact as a factor in word-order change is provided by the contemporary geographical environments of verb-initial and subject-initial Chadic languages. Those Chadic languages that are subject-initial are in contact with subject-initial languages from Chadic or other families (see map).

There is also anecdotal evidence that word-order change can be rather rapid. While working on the verb-initial language Hdi, Z.F. came across two Hdi speakers who had left the village some time before and moved to an urban environment. Elicited sentences produced by these speakers were consistently subject-initial. Similarly, in Heusing 1999, all clauses are subject-initial in sentences elicited from a Hdi speaker in Nigeria. This speaker was a student at the University of Maiduguri and had extensive contact with speakers of Hausa and, potentially, other subject-initial languages. The ultimate test of whether the Hdi of those speakers has undergone a change would be natural language texts, which, however, were not recorded.

We have shown that unrelated languages exhibit similar language-internal conditions for the development of a typologically rare phenomenon. However, the phenomenon does not necessarily occur in all languages with these internal conditions. We conclude that when language-internal factors are combined with language contact, and when both factors favor the same outcome, the change is more likely to occur than when there is absence of contact with languages having similar structures. If only one of the language-internal motivations is present, or if the language-internal motivations lead to different outcomes in different languages, the change is less likely to occur. Thus, although lexical borrowings provide evidence that Wandala, whose basic structure is Pronoun-Verb-Nominal subject, has had extensive contact with the verb-final language Kanuri (Nilo-Saharan), there has been no change in the direction of verb-final order in Wandala.

\section{Conclusions}

We have shown that identical structures can exist in unrelated languages that are geographically remote from one another, provided the languages have internal prerequisites for the grammaticalization of the structures. One prerequisite for the structure Subject pronoun [person]Verb-[number] is for the language to have the number of the argument coded as a category separate from person and gender. The other prerequisite is the requirement for overt coding of the subject pronoun before the verb, at least in some constructions. It is only when these two conditions are met at the same time that the structure Subject pronoun [person]-Verb-[number] may emerge. This hypothesis may appear to be circular, but it is not: If the number is coded as a separate category but the subject pronoun does not have to be overtly coded, the relevant structure does not occur. This seems to be what happens in Lakhota, where the third person is unmarked but plurality of the subject is marked. Similarly, when the number marker has fused with another category, such as the 
object pronoun, and as a result has lost its morphological identity, the relevant structure does not emerge.

Having established similar starting conditions, i.e. similar forms carrying similar functions, we can explain the independent grammaticalization of subsequent constructions that also have similar functions. In the case in question, the split coding of person and number results in the emergence of similar constructions for coding grammatical relations in unrelated languages. The processes that lead to the emergence of similar constructions may be quite different across languages. We have demonstrated that the occurrence of identical, typologically rare structures in abutting languages can be explained by language-internal changes. We have also shown that contact between languages with similar language-internal conditions may well increase the likelihood that the languages will evolve similar structures.

\section{References}

Barreteau, Daniel. 1988. Lexique Mafa. Paris: ORSTOM.

Barreteau, Daniel. 1988. Description de Mofu-Gudur: Lexique (Livre II). Paris: ORSTOM.

Bhat, Darbhe Narayana Shankara. 2005. Third-person pronouns and demonstratives. In Haspelmath et al. 178-81.

Colombel, Véronique de. 1998. Les pronoms dans une dizaine de langues des monts du Mandara. Linguistique Africaine 21. 95-110.

Daniel, Michael. 2005. Plurality in independent personal pronouns. In Haspelmath et al. 2005, 146149.

Dittemer, Clarissa, Ibriszimow, Dymitr \& Karsten Brunk. 2004. Les pronoms en tchadique: vue d'ensemble. In Dymitr Ibriszimow \& Guillaume Segerer (eds.), Systèmes de marques personnelles en Afrique, 55-96. Louvain-Paris: Peeters.

Elders, Stefan. 2000. Grammaire Mundang. Leiden: CNWS.

Frajzyngier, Zygmunt. 1983. Marking Syntactic Relations in Proto-Chadic. In E. Wolff \& H. Meyer-Bahlburg (eds.) Studies in Chadic and Afro-Asiatic Linguistics, 115-138. Hamburg:Buske.

Frajzyngier, Zygmunt. 1997. Grammaticalization of number: From demonstratives to nominal and verbal plural. Linguistic Typology 1:193-242.

Frajzyngier, Zygmunt. 2004. Tense and aspect as coding means. In Bernard Comrie \& Ekkehard Wolff (eds.) Journal of West African Languages XXX.2: 53-67. Special issue.

Frajzyngier, Zygmunt. 2008. A Grammar of Gidar. Frankfurt: Peter Lang.

Frajzyngier, Zygmunt. In progress. A Grammar of Wandala.

Frajzyngier, Zygmunt, \& Erin Shay. 2002. A Grammar of Hdi. Berlin - New York: Mouton de Gruyter.

Frajzyngier, Zygmunt, \& Erin Shay (eds.). To appear a. Interaction of Morphology and Syntax: Case studies in Afroasiatic. Amsterdam - Philadelphia: John Benjamins. 
Frajzyngier, Zygmunt, \& Erin Shay (eds.). To appear b. Afroasiatic Languages. Cambridge: Cambridge University Press.

Greenberg, Joseph H. 1978. How does language acquire gender markers? In Joseph H. Greenberg. (ed.), Universals of Human Language, 48-82. Stanford: Stanford University Press.

Haspelmath, Martin, Matthew S. Dryer, David Gil, \& Bernard Comrie. 2005. The world atlas of language structures. Oxford: Oxford University Press.

Heusing, Gerald. 1999. Aspects of the Morphology-Syntax Interface in Four Nigerian Languages. LIT Verlag.

Kurylowicz, Jerzy. 1964. The inflectional categories of Indo-European. Heidelberg: Carl Winter Universitätsverlag.

Löhr, Doris. 1999. Die Sprache der Malgwa. Frankfurt am Main: Peter Lang.

Loprieno, Antonio \& Matthias Müller. Egyptian. In Frajzyngier \& Shay (eds.), to appear b.

Lukas, Johannes. 1970. Studien zur Sprache der Giziga (Nordkamerun). Afrikanische Forschungen, Band IV. Glückstadt: Augustin.

Ross, Malcolm. 2007. Calquing and metatypy. Journal of Language Contact. Thema 1:116-143, www.jlc-journal.org/.

Ruelland, Suzanne. 1992. Description du parler tupuri de Mindaoré, Mayo-Kebb (Tchad). Phonologie, morphologie, syntaxe. Lille: Atelier national de réproduction des thèses, Université de Lille III (cited from Elders 2000).

Ruelland, Suzanne. 2000. Topicalisation et focalisation en Tupuri. In B. Caron (ed.), Topicalisation et focalisation dans les langues africaines, 135-159. Louvain: Peeters.

Schuh, Russell G. 1983. The evolution of determiners in Chadic. In Ekkehard Wolff \& Hilke Meyer-Bahlburg (eds.), Studies in Chadic and Afroasiatic Linguistics, 157-210. Hamburg: Buske.

Shay, Erin. To appear. Coding the unexpected: Subject pronouns in East Dangla. In Frajzyngier \& Shay (eds.), to appear a.

Shay, Erin. In progress. A Grammar of Giziga.

Tourneux, Henry, 2004. Les marques personnelles en kotoko et en mafa/wandala. In D. Ibriszimow \& G. Segerer (eds.), Systèmes de marques personnelles en Afrique, 199-212. Paris-Louvain: Peeters.

Zaborski, Andrzej. 1975. The verb in Cushitic. Warsaw-Cracow: Panstwowe Wydawnictwo Naukowe. 


\section{Abbreviations}

\begin{tabular}{|c|c|c|c|}
\hline ABL & Ablative & LOC & Locative \\
\hline ALL & Allative & M & Masculine \\
\hline ALSO & Verbal extension coding truth & NEG & Negative \\
\hline APPL & Applicative & OBJ & Object \\
\hline Ar. & Arabic & PARTCPL & Participle \\
\hline ASSOC & Associative & PL, Pl & Plural \\
\hline $\mathrm{COM}$ & Comment marker & PERF & Perfect \\
\hline COMP & Complementizer & $\mathrm{PO}$ & Potential object extension \\
\hline COMPL & Completive & PRED & Predicate \\
\hline DAT & Dative & PREP & Preposition \\
\hline DEF & Definite & PRF & Perfect \\
\hline DEM & Demonstrative & PROG & Progressive \\
\hline $\mathrm{D}: \mathrm{PVG}$ & Distal extension: Point of & PROX & Proximate, proximal \\
\hline \multirow[t]{2}{*}{ D:SO } & \multirow{2}{*}{$\begin{array}{l}\text { Distal extension: Point of } \\
\text { view of source }\end{array}$} & $\mathrm{Q}$ & $\begin{array}{l}\text { Question, interrogative } \\
\text { marker }\end{array}$ \\
\hline & & REF & Referential \\
\hline EE & End of event & REL & Relative \\
\hline EX, EXCL & Exclusive & $\mathrm{S}$ & Subject, singular \\
\hline $\mathrm{F}$ & feminine & SEQ & Sequential \\
\hline FUT & Future & $\mathrm{SG}, \mathrm{Sg}$ & Singular \\
\hline FOR & Preposition 'for' & SO & Point of view of source \\
\hline GEN & Genitive & TO & Preposition 'to' \\
\hline GO & Goal & TOT & Totality \\
\hline Hau. & Hausa & UP & Verbal extension 'up' \\
\hline HYP & Hypothetical & $\mathrm{V}$ & Vowel \\
\hline IM & Imperfective & VENT & Ventive \\
\hline IN & Verbal extension 'in' & $\mathrm{VN}$ & Verbal noun \\
\hline INCL & Inclusive & & \\
\hline INTENS & Intensifier & & \\
\hline
\end{tabular}




\section{FRONTIER RESEARCH}


Journal of language contact - THEMA 2 (2008) www. jlc-journal.org 